\title{
Proliferating cell nuclear antigen (PCNA), p53 and MDM2 expression in Hodgkin's disease
}

Division of Hematology and Transfusion Medicine, Hospital São Paulo, Universidade Federal de São Paulo - Escola Paulista de Medicina (Unifesp-EPM), São Paulo, Brazil

INTRDDUCTION

Hodgkin's disease (HD) is a neoplasm that has the characteristic of containing a small number of scattered large multinucleated or mononucleated cells, designated ReedSternberg cells and Hodgkin cells respectively, residing in a heterogeneous admixture of inflammatory and accessory cells. ${ }^{1,2}$ The paucity of Hodgkin and Reed-Sternberg (HRS) tumor cells initially made it difficult to determine the origins of these cells. ${ }^{1-3}$ However, high-density genomic expression and immunoglobulin $\mathrm{H}$ $(\mathrm{IgH})$ variable-region gene rearrangements using single-cell analysis obtained by microdissection techniques have now demonstrated an origin in germinative B cell centers. ${ }^{4-9}$

There are few previous studies in the literature evaluating cell proliferation and this may be explained by the complex nature of this neoplasm and its heterogeneous cell composition. ${ }^{10}$ It has already been described that, in HD, HRS cells express proliferating cell nuclear antigen (PCNA) and $\mathrm{p} 53$ in more than $50 \%$ of the cases and that these expressions may play a role in the pathogenesis of the disease. ${ }^{11}$ PCNA is a cell cycle-associated protein that interferes with cell proliferation in normal and tumor cells. It is an essential protein in DNA repair. PCNA is detected by positive reaction for the monoclonal antibody PC-10. ${ }^{10,11}$ PCNA activity in DNA repair increases resistance to chemotherapy in which the cytotoxicity depends on its integrity. ${ }^{12}$ PCNA expression in relapsed HD is greater than at diagnosis. ${ }^{12}$

Wild-type $\mathrm{p} 53$ protein encoded by the $p 53$ gene acts in the cell cycle to interrupt it at the G1 phase. ${ }^{13}$ This suppressive activity allows DNA repair in injured cells and avoids apoptosis. ${ }^{14}$ Deletion or mutation of $p 53$ is classically associated with p53 tumor activity. ${ }^{13-15}$ Mutated p53 has a mean half-life of six to eight hours and no suppressive action, and it is easily detectable by immunohistochemistry methods. Mutated p53 replaces the wild-type p53 that is present in low intracellular concentrations, and has a shorter half-life of $20 \mathrm{~min} \cdot{ }^{13-16} p 53$ mutation is missense and occurs mainly between exons 5 and $9 .{ }^{15,16} p 53$ mutations lead to loss of suppressive function, thereby accelerating tumor genesis. ${ }^{13,14}$ p 53 overexpression has been widely detected in $\mathrm{HD}$, even in the absence of known p53 mutations. ${ }^{12,15,17-20}$ The MDM2 (murine cell double minute-2) gene encodes the $\mathrm{p} 90$ protein, which binds to wild-type $\mathrm{p} 53^{17,18}$ to inhibit its suppressive activity in transcription. ${ }^{19,20}$ Associated expression of $\mathrm{p} 53$ and MDM2 is present in more than $90 \%$ of HD cases. ${ }^{17-19,21}$

The Epstein-Barr virus (EBV) genome is found in up to $50 \%$ of cases of HD. ${ }^{22}$ EBNA-1 (Epstein-Barr nuclear antigen-1) bonds with $\mathrm{p} 53$ and it has been suggested that EBNA-1 expression results from that interaction. ${ }^{23}$ The exact role of EBV in HD genesis is not clear yet. ${ }^{22,23}$

\section{口BJECTIVE}

The present study had the aims of evaluating $\mathrm{P} 53$, PCNA and MDM2 protein expression using immunohistochemical methods, on formalin-fixed, paraffin-embedded preserved tissue samples used for HD diagnosis, and correlating these expressions with clinical and laboratory parameters in order to evaluate their impact on HD outcome.

\section{PATIENTS AND METHODS}

\section{PATIENTE}

Our sample consisted of 126 patients with $\mathrm{HD}$ that were followed up over the period from Janaury 1992 to December 1996 at Hematology Division of Unifesp/EPM. The admissions for the first-line treatment of these patients were from December 1976 to December 1996. Sufficient paraffin-embedded blocks of diagnostic tissues were available in relation to 51 patients from this sample for performing new histological analyses with hematoxylin-eosin staining and for making immunohistochemistry slides
- Gevina Silva Pinheiro

- Maria Regina Régis Silva

- Celso Arrais Rodrigues

Iosé Kerbauy

- José Salvador Rodrigues de Oliveira

\section{ABSTRACT}

CONTEXT AND OBJECTIVE: Tumor cells in Hodgkin's disease (HD) express cell proliferation markers that are evaluated according to the onco-
genes involved or the expression of their proteins. genes involved or the expression of their proteins.
Correlations between the protein expression grade and clinical data are now important for disease prognosis.

DESIGN AND SETTING: This was a retrospective analysis on proliferating cell nuclear antige (PCNA), p53 and MDM2 (murine double minute-2) expression using immunohistochemistry, on formalinfixed paraffin-embedded tissues from diagnostic biopsies on 51 patients with HD. The slagnostic biopsies on 51 palients wish HD. The study was conducted at the Division of Hematology and Transfusion Medicine, Hospital São Paulo, Universidade Federal de São Paulo.

METHODS: Antigen expression was evaluated as the proportions of positive Hodgkin and Reed Sternberg (HRS) cells and reactive lymphocytes (L), which were compared using Spearman correlation coefficients. The Friedman test was used for comparisons between the markers. The Pearson test was used to investigate associations between marker expression and clinical and laboratory pamarker expression and clinical and laboratory pant, complete remission (CR) and overall survival (OS) rates.

RESULTS: There was overexpression of antigen proteins in HRS, in relation to $L(p<0.001)$. In HRS, MDM2 was higher than $p 53$ and PCNA $(p<0.003)$, while the latter two were equivalent. In L, p53 was lower than MDM2 and PCNA $(p<0.001)$, while the latter two were equivalent. There was no relationship between protein expression and clinical and laboratory variables or outcome.

CONCLUSIONS: PCNA, p53 and MDM2 are tumor markers for $\mathrm{HD}$, but showed no clinical or prognostic significance in our analysis.

KEY WORDS: Proliferating cell nuclear antigen. p53 genes. Proto-oncogene proteins c-mdm2 Hodgkin disease. Immunohistochemistry. 
for PCNA, p53 and MDM2 analysis. Fifty-one other patients out of the remaining 75 were randomly selected as a control group. The paraffin-embedded blocks were obtained from the Pathology Department of Unifesp.

The patients' records were retrospectively reviewed to collect data on gender, age, Ann Arbor clinical stage, B symptoms (fever, weight loss and night sweating), histological subtype, hemoglobin level, white blood count (WBC), erythrocyte sedimentation rate (ESR), alkaline phosphates and bone marrow involvement. First complete remission (CR) and overall survival (OS) were also evaluated (Table 1). Nine of these patients (six in the study group and three in the control group) were not evaluated with regard to the achievement of first CR and OS, but they had diagnostic and staging data available and therefore they were included because of these criteria.

The first patient was treated and followed up starting in 1976 and the remainder from 1980 onwards. Subsequently, the treatment protocols changed over the course of time. Patients treated before 1985 received chemotherapy using the MOPP (mechlorethamine, vincristine, prednisone and procarbazine) protocol, while those treated after that year received either the MOPP/ABV (MOPP plus doxorubicin, bleomycin and vincristine) hybrid protocol or the MOPP/ABVD (ABV plus dacarbazine) alternative regimen. ${ }^{24}$ Involved-field radiation therapy was performed on all stage I and II pa- tients and on most stage III patients, except those with bulky disease, who received extended-field radiation therapy. ${ }^{24}$

There were no significant differences between the control and study groups with regard to the following variables: age $(\mathrm{p}=0.19)$, hemoglobin level ( $\mathrm{p}=0.99)$, WBC ( $=0.53), \operatorname{ESR}(\mathrm{p}=0.37)$ $\mathrm{A}$ and $\mathrm{B}$ symptoms $(\mathrm{p}=0.14)$, bone marrow infiltration ( $p=0.46$ ), likelihood of achieving the first complete remission (CR) ( $p=0.68)$, overal survival (OS) ( $\mathrm{p}=0.83)$ and stages $(\mathrm{I}+\mathrm{II}, \mathrm{III}+\mathrm{IV})$ $(p=0.99)$. In relation to histological subtypes (LP $+\mathrm{NE}),(\mathrm{MC}+\mathrm{LD})(\mathrm{LP}=$ lymphocyte predominance; $\mathrm{NE}=$ nodular sclerosis; $\mathrm{MC}=$ mixed cellularity; $\mathrm{LD}=$ lymphocyte depletion) ( $\mathrm{p}=0.03$ ), greater frequency of $\mathrm{NE}$ in the study group than in the control group was observed.

Forty-five out of 51 patients in the study group and 48 out of 51 in the control group could be evaluated regarding achievement of first CR and OS. There were 12 deaths: 7/48 $(14 \%)$ and $5 / 45(11 \%)$ in the control and studied groups, respectively.

This study was approved by the Ethics Committee of Universidade Federal de São Paulo, and informed consent was obtained from all subjects who were still alive.

\section{METHRDg}

All the lymph node biopsies were preserved in formalin and embedded in paraffin. Samples were then restained using the hematoxylin-eosin method and reviewed

Table 1. Dichotomization and coding of variables evaluated

\begin{tabular}{|c|c|c|}
\hline & & \\
\hline Variable & 0 & 1 \\
\hline Gender & Male & Female \\
\hline Age & $<40$ years & $\geq 40$ years \\
\hline Histological subtype & LP and NE & $M C$ and LD \\
\hline Clinical stage & I and II & III and IV \\
\hline B Symptoms & No & Yes \\
\hline Hemoglobin Level & $<12 \mathrm{~g}$ & $\geq 12 \mathrm{~g}$ \\
\hline WBC & $<10 \times 10^{9} / 1$ & $\geq 10 \times 10^{9} / 1$ \\
\hline ESR & $<20 \mathrm{~mm}$ & $\geq 20 \mathrm{~mm}$ \\
\hline Alkaline phosphatase & $<150 \mathrm{U}$ & $\geq 150 \mathrm{U}$ \\
\hline $\begin{array}{l}\text { Bone marrow involve- } \\
\text { ment* }^{*}\end{array}$ & Negative & Positive \\
\hline$\% \mathrm{HRS}+\mathrm{MDM} 2$ & $<$ median (= 59.37\%) & $\geq$ median \\
\hline$\% \mathrm{HRS}+\mathrm{PCNA}$ & $<$ median $(=52.72 \%)$ & $\geq$ median \\
\hline$\% H R S+p 53$ & $<$ median $(=53.45 \%)$ & $\geq$ median \\
\hline
\end{tabular}

$L P=$ lymphocyte predominance; $N E=$ nodular sclerosis; $M C=$ mixed cellularity; $L D=$ lymphocyte depletion; $W B C=$ whole blood count; $E S R=$ erythrocyte sedimentation rate; $H R S=$ Hodgkin and Reed-Sternberg cells; MDM2 = murine double minute-2 antigen; $P C N A=$ proliferating cell nuclear antigen; ${ }^{*}$ bone marrow infiltration: positive: presence of bone marrow involvemen of $H D$; negative: absence of bone marrow $H D$ infiltration.

by two hematopathologists. The minimum immunohistochemistry panel consisted of anti-CD30 and CD15 antibodies. Once HD had been confirmed, PCNA, p53 and MDM2 antibodies were also included. The tissue sections underwent routine treatment. Antigenic recovery was performed by immersing the slides in $0.001 \mathrm{M}$ citrate buffer $(\mathrm{pH}$ 6.0) and heating in a microwave oven at maximum power for 45 minutes. After cooling for 20 minutes at room temperature, the slides were washed under running water for five minutes and distilled water for a further five minutes. Endogenous peroxidase was then blocked by immersing the slides in a $0.006 \%$ hydrogen peroxide solution for two nine-minute periods, each followed by rinsing using distilled water and phosphate buffer solution (PBS).

Monoclonal antibodies were added at the concentrations recommended by the manufacturer, as follows. For PCNA: PC-10 (Dako, catalog no. MO-879) at 1/200 concentration for 18 hours at $4^{\circ} \mathrm{C}$, followed by PBS washing; for MDM2: MDM2 (Novocastra, catalog no. NCR-MDM2) at 1/200 concentration; and for p53: DO7 (Novocastra, catalog no. NCL-p53DO7) and BP (Novocastra, catalog no. NCL-p53BP), at 1/50 concentration for both, incubated for 18 hours at $4^{\circ} \mathrm{C}$. The secondary antibody was biotinylated rabbit anti-mouse (Dako, catalog no. E-0354), at $1 / 100$ concentration. Development occurred after incubation with the streptavidin-biotinperoxidase-ABC complex (Dako, catalog no. $\mathrm{K}-377 \mathrm{~A}-\mathrm{B})$, at $1 / 200$ concentration for 30 minutes at $37^{\circ} \mathrm{C}$, followed by development on a chromogenic substrate of 3,3' diaminobenzidine (PAB-Sigma, catalog no. D-5637) at $0.006 \%$ concentration in PBS, adding $100 \mu \mathrm{l}$ of hydrogen peroxide at 30 volumes for each $10 \mathrm{ml}$ of solution. ${ }^{25}$

The PCNA samples were counterstained with Fast-Green (Inlab, catalog no. 3870) and p53 and MDM2 with Harris hematoxylin. Negative controls were obtained from distinctive parts of the same slide, by omission of the tested monoclonal antibody. Positive controls were obtained from breast cancer slides that were known to be positive for $\mathrm{p} 53$, MDM2 and PCNA, which were provided by the pathology department of our institution. The number of positive cells was determined from the HRS and L counts. Positive cells were defined as all cells with any pattern of nuclear staining; negative cells were those without this. Two of the present authors performed the counting, using an optical microscope at a magnification of 1000 times, 
with a 100 -dot integrator (Zeiss), in five randomly chosen different fields. In every case, a positive-negative ratio was calculated for HRS and L after specific and general proportion ratios for positive and negative $\mathrm{L}$ and HRS cells had been obtained.

\section{STATIBTICAL ANALYGIB}

The tests used were the Wilcoxon test and Spearman coefficient to compare marker expression between HRS and L, Friedman's test to determine differences between the markers (PCNA, p53 and MDM2) in HRS and L, and Pearson's chisquared test to evaluate clinical and laboratory variables. CR achievement and OS were calculated by the Kaplan-Meier method and the curves were compared using log-rank tests. Multivariate analysis was based on the Cox regression model. Variables were dichotomized for univariate and multivariate analysis regarding CR achievement and OS. Two-tailed $\mathrm{p}<0.05$ was considered statistically significant.

RESULTS

There was preponderance of male subjects: 34 patients were male $(67 \%)$ and 17 were female $(33 \%)$. Their ages ranged from 9 to 88 years (median: 32 years). Nodular sclerosis was the most common histological subtype and was found in 38 patients $(74.5 \%)$, followed by mixed cellularity in seven patients $(13.7 \%)$, lymphocyte depletion in three $(5.8 \%)$ and lymphocyte predominance in three (5.8\%). Ann Arbor clinical stage I was found in three patients (5.8\%), II in 14 (27.4\%), III in $16(31.3 \%)$ and IV in 18 (35.3\%). Therefore, 66.6\% had advanced disease (stage III or IV) at diagnosis. Moreover, 36 out of the 51 patients $(72.5 \%)$ presented with B symptoms.

The first-line therapy was thus the MOPP/ ABV hybrid for 39 patients, MOPP for six patients and the MOPP/ABVD alternative scheme in four cases. ${ }^{24}$ Involved-field radiation therapy was performed in 28 cases and extended-field radiation therapy in 12 patients.

The median hemoglobin level was $11.7 \mathrm{~g} / \mathrm{dl}$ (ranging from $4.4 \mathrm{~g} / \mathrm{dl}$ to $16.3 \mathrm{~g} / \mathrm{dl}$ ), median WBC was $8 \times 10 \%$, median ESR was $58 \mathrm{~mm} / \mathrm{h}$ and median alkaline phosphatase was $233 \mathrm{U} / \mathrm{l}$. Bone marrow analysis was negative in 40 patients, positive in eight and not available in three patients.

The mean MDM2 expression was $60 \%$ in HRS and $20.7 \%$ in L ( $<<0.001)$. For $\mathrm{p} 53$, the mean expression was $52.9 \%$ in HRS and $5.9 \%$ in $\mathrm{L}(\mathrm{p}<0.001)$. For PCNA, the mean expression was $53.4 \%$ in HRS and $20 \%$ in $\mathrm{L}$ ( $\mathrm{p}<0.001$ ) (Graphs 1, 2 and 3 and Tables 1, 2, 3 and 4). The expression of these tumor markers in HRS was predominantly in the nucleus, and was more positive in tumors than in reactive lymphocytes, for all three markers (Figures 1, 2 and 3 and Graphs 1, 2, 3 and 4).

PCNA, p53 and MDM2 were not associated with gender, age, clinical stage, B symptoms, histological subtype, hemoglobin level, WBC, alkaline phosphatase, ESR or bone marrow involvement (Tables 2, 3 and 4). Univariate analysis between the proportions of marker expression in the tumor cells and all other variables investigated showed tendencies to correlate between MDM2 and PCNA ( $\mathrm{p}=0.07)$ (Graph 5, Table 2); PCNA and p53 $(\mathrm{p}=0.12)$ (Graph 5 and Tables 3 and 4); alkaline phosphatase index higher than 150 $\mathrm{U}$ and MDM2 ( $\mathrm{p}=0.09$ ); and unfavorable histology and $\mathrm{p} 53(\mathrm{p}=0.15)$ (Tables 1,2 , 3 and 4), but there was no association of marker expression between MDM2 and p53 ( $\mathrm{p}=0.88$ in the Kaplan-Meier test) (Graph 5 and Tables 3 and 4). Multivariate statistical analysis also showed no significant differences.

The expression of different markers had no significant influence on $\mathrm{CR}$ achievement: $\mathrm{p} 53(\mathrm{p}=0.49) ;$ MDM2 ( $=0.59)$ and PCNA $(\mathrm{p}=0.62)$. No significant influence on OS was found in relation to PCNA ( $p=0.13)$, MDM2 $(\mathrm{p}=0.21)$ or $\mathrm{p} 53(\mathrm{p}=0.54)$. The median OS for the study and control groups has not yet been reached. Therefore, we used the whole available population of 93 patients to analyze any possible associations for first $\mathrm{CR}$ and $\mathrm{OS}$ in relation to the other variables. The univariate analysis for the likelihood of achieving the first CR showed that B symptoms $(\mathrm{p}<0.001)$, WBC $\geq 10 \times 10 \% / \mu \mathrm{l}$ $(\mathrm{p}=0.01)$, stage (III + IV) $(\mathrm{p}=0.01)$ and hemoglobin $<12 \mathrm{~g} / \mathrm{dl}(\mathrm{p}=0.04)$ negatively influenced the possibility of achieving this. The results for bone marrow infiltration $(p=0.07)$ and age

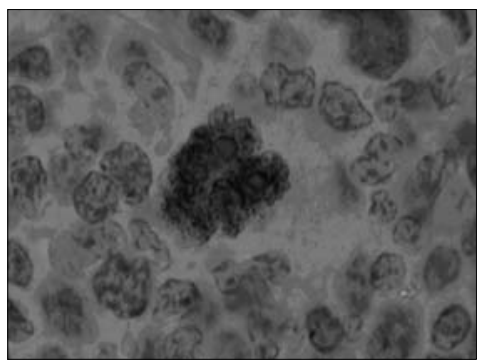

Figure 1. Photomicrograph of lymph node showing nuclear p53 expression in Reed-Sternberg cells, developed by peroxidase; 1000x magnification.
( $p=0.17$ ) were close to reaching significance. The Cox regression model indicated that $\mathrm{B}$ symptoms $(\mathrm{p}=0.001)$ and $\mathrm{WBC} \geq 10 \times 10^{\%} / \mu \mathrm{l}$ $(p=0.01)$ were independent from the other analyzed variables in relation to the first CR.

All the patients without B symptoms $(\mathrm{n}=22)$ and those with ESR less than $20(\mathrm{n}=7)$ were still alive at the end of this study. However these findings made it impossible to input these variables for multivariate analyses for OS.

In the univariate analysis, marrow involvement $(p=0.05)$, hemoglobin $<12 \mathrm{~g} / \mathrm{dl}$ $(\mathrm{p}=0.06), \mathrm{WBC} \geq 10 \times 10 \% \mathrm{\mu l}(\mathrm{p}=0.07)$ and male sex $(\mathrm{p}=0.1)$ showed tendencies towards lower OS. The log rank test demonstrated that bone marrow infiltration ( $\mathrm{p}=0.002)$, B symptoms $(\mathrm{p}=0.03)$ and hemoglobin $<12 \mathrm{~g} / \mathrm{dl}$ $(\mathrm{p}=0.04)$ had a negative influence on OS. With regard to the CR ratios, 33/45 (73.3\%) in the study group and 36/48 (75\%) among the controls achieved CR; 6/45 (13.3\%) in the study group and 3/48 (6.2\%) among the controls obtained partial response; and 6/45 $(13.3 \%)$ in the study group and 9/48 (18.7\%) among the controls failed to achieve remission after the first treatment measures.

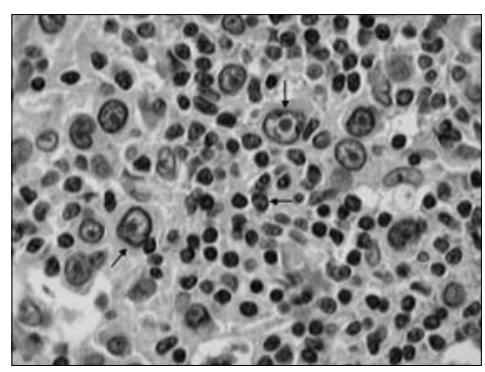

Figure 2. Photomicrograph of lymph node showing nuclear MDM2 expression in Hodgkin cells (upper right and left arrows) and lymphocytes (lower right arrow), developed by peroxidase; $400 x$ magnification.

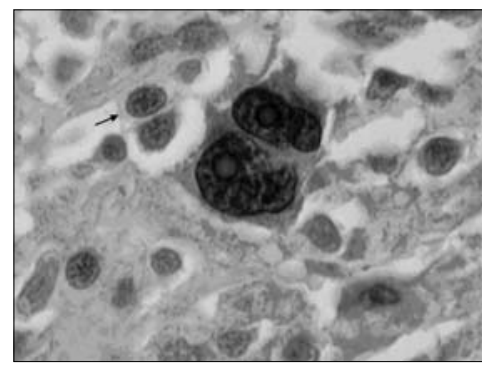

Figure 3. Photomicrograph showing nuclear PCNA expression in Reed-Sternberg cells and some Hodgkin cells (arrow), developed by peroxidase; 1000x magnification. 
Graph 1. Dispersion of proportional values for MDM2 expression between Hodgkin and Reed-Sternberg (HRS) cells and lymphocytes (L).

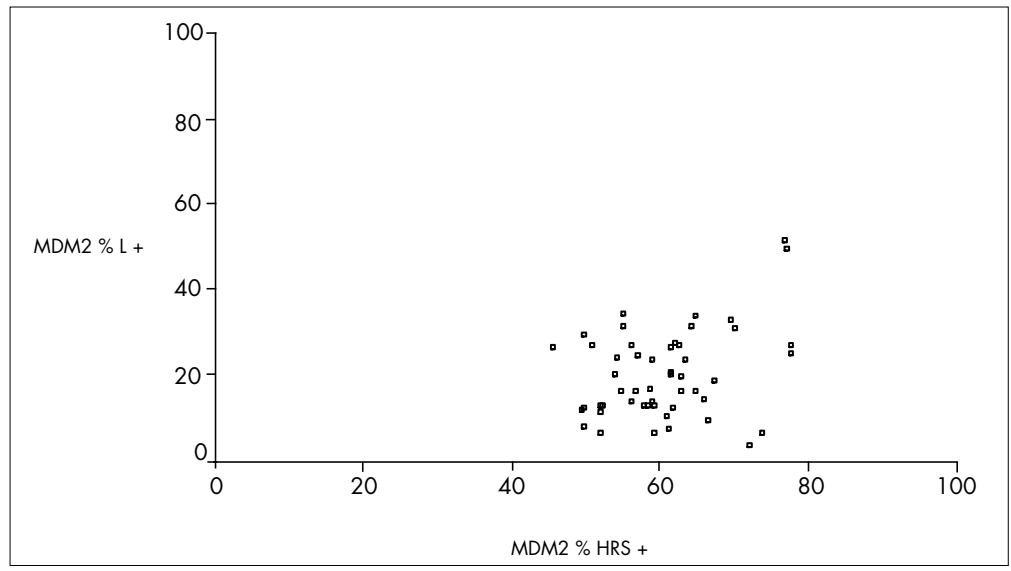

Graph 2. Dispersion of proportional values for p53 expression between Hodgkin and Reed-Sternberg (HRS) cells and lymphocytes (L).

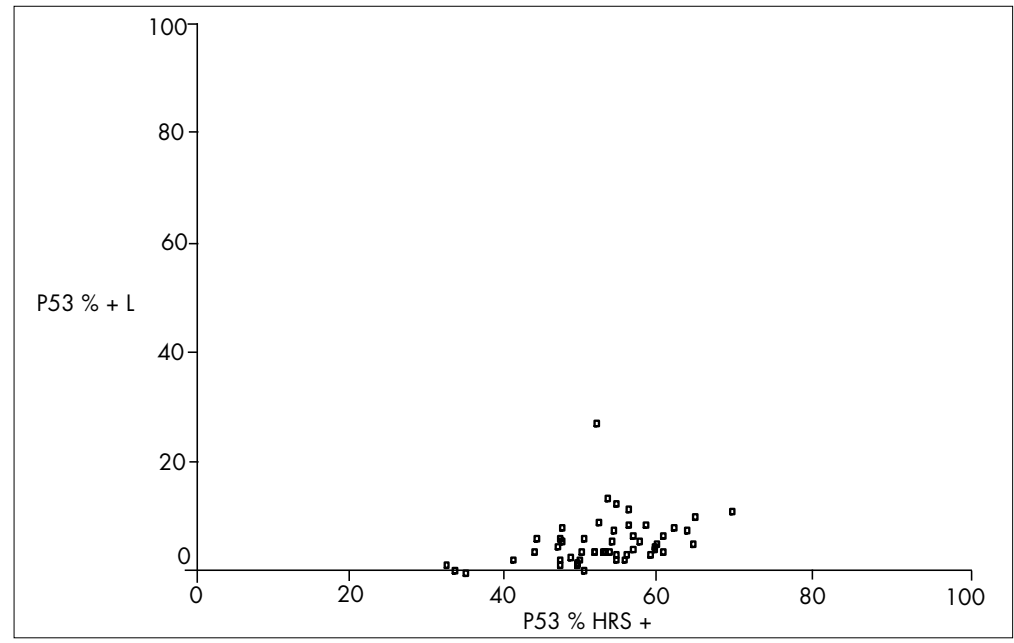

Graph 3. Dispersion of proportional values for proliferating cell nuclear antigen (PCNA) expression between Hodgkin and Reed-Sternberg (HRS) cells and lymphocytes (L).

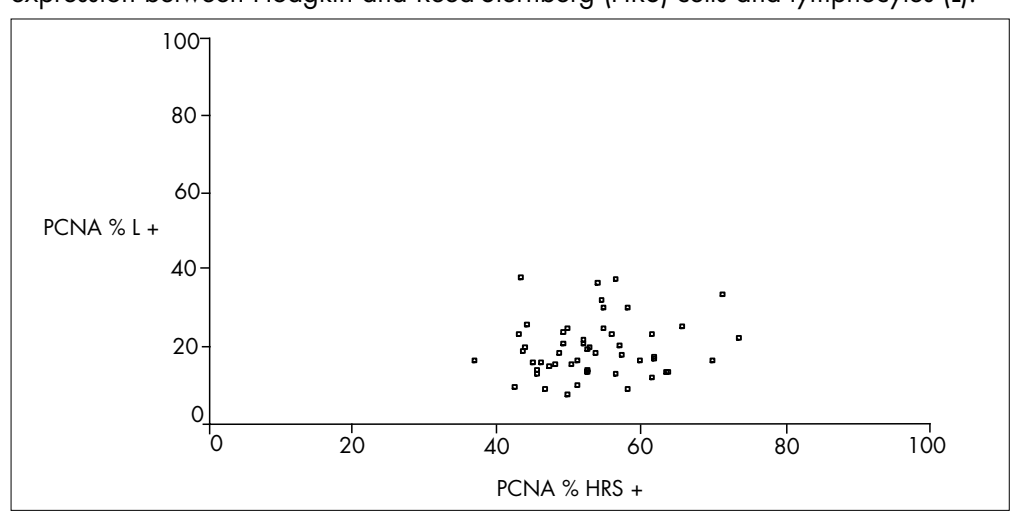

DISCUSSION

$\mathrm{HD}$ is a unique human neoplasm consisting of a benign component of lymphocytes, plasmacytes, eosinophils and neutrophils with evident cellular polymorphism, in association with a much smaller component of tumor cells (HRS) comprising around $1 \%$ of the tumor mass. ${ }^{1-3}$

The cell proliferation rate is an important parameter for better understanding of the clinical picture and for guiding the appropriate therapy. PCNA monoclonal antibodies allow cell proliferation to be evaluated in clinical practice using immunohistochemical methods. ${ }^{10-12}$ In non-neoplastic small lymphocytes in HD tissues, PCNA expression is always low. ${ }^{10-12,26,27}$ Schmid et al. ${ }^{28}$ evaluated 23 cases of HD by double labeling with PC-10 monoclonal antibody and CD20 (B cells), and PC-10 and CD45RO (T cells), and found positivity in $50.4 \%$ of HRS and $4.3 \%$ of lymphocytes. HRS cells express PCNA in 5 to $100 \%$ of the cases. It has been demonstrated that the intensity of PCNA expression has an influence over clinical stages and response to treatment. ${ }^{12,27,28}$

We found PCNA-positive rates for HRS cells that ranged from $36.9 \%$ to $73.68 \%$ (median of 52.7\%), which were similar to previously reported studies. ${ }^{10-12}$ We found higher values for PCNA in reactive lymphocytes than did most previous researchers (median of 18.8\%). ${ }^{12,27,28}$ These differences are probably due to variations in the methods and discrepancies in manual cell counts between the individuals doing the counting.

There are many studies evaluating $\mathrm{p} 53$ and MDM2 expression in neoplasms. $p 53$ mutations without differences in protein expression have been reported. ${ }^{15,17-19,21,22} \mathrm{We}$ characterized $\mathrm{p} 53$ using two different clones: $\mathrm{BP}$ and DO7. $\mathrm{p} 53$ expression was similar for these two clones (data not shown). This indicates that $\mathrm{p} 53$ expression in the wild type or in the mutated form may be evaluated using immunohistochemical methods either in fresh tissue or in formalin-fixed, paraffin-embedded preserved material. The application of this analysis depends on the characteristics and specificity of the monoclonal or polyclonal antibodies for $\mathrm{p} 53 .^{15,16,20,26,29}$

Latent EBV infection was initially suggested as a possible cause for $p 53$ mutation. This hypothesis has never been confirmed in clinical studies. The possibility of an association between latent EBV infection and p53 was first evaluated by Neidobitek et al..$^{30}$ in 37 patients in 1993. Only seven cases that were positive for $\mathrm{p} 53$ were also positive for 
EBV proteins (EBER-1 or EBER-2). It is assumed that an association between $\mathrm{p} 53$ and EBV could be a consequence of EBV encoding proteins that are bonded to $\mathrm{p} 53$. Chilosi et al. ${ }^{17}$ investigated nuclear EBV using in situ hybridization for EBER-1 and immunohistochemistry for LMP-1 after double staining for $\mathrm{p} 53$ and MDM2. They found that 12 out of 72 patients who were positive for EBV were also positive for MDM2 and p53 concomitantly.

The role of MDM2 protein expression in activating/inhibiting the $p 53$ gene and in stabilizing $\mathrm{p} 53$ has also already been studied. Chen et al. ${ }^{20}$ showed that there was no relationship between MDM2 expression and p53 mutations. MDM2 and p53 expression in HRS cells ranged from 30 to $80 \%$. $^{12,17,21,26}$ In our study, concomitancy of $\mathrm{p} 53$ and MDM2 was found in only $37 \%$ of the cases. The lowest marker expression in reactive lymphocytes that we found, especially for $\mathrm{p} 53$, was comparable to previous descriptions. $12,16,17,21,26$ Positive lymphocyte reactions for PCNA and MDM2 at similar frequencies have also often been reported. ${ }^{10-12,17,18,26,31}$ Our positive results for PCNA, p53 and MDM2 in HRS cells are similar to those described by Martinez-Delgado et al. ${ }^{29}$ and Sánchez-Beato et al. ${ }^{26}$ In both of those studies, double staining for p53/MDM2 was performed and variable marker expression in HRS cells was also found.

Using histomorphometric techniques taking median values as thresholds, we found that the numerical expression of MDM2 was higher than those of PCNA and $\mathrm{p} 53$ in HRS cells, while there was no difference between PCNA and p53 expressions. The possible explanations for this finding are: 1) the antigen recovery technique utilized may have led to higher expression of epitopes for MDM2specific antibodies; 2) MDM2 protein stability may be higher in formalin-fixed, paraffin-embedded tissue; 3) the characteristics of the antibodies utilized; and 4) the balance between the p53 and MDM2 pathways may favor MDM2 expression because of other mechanisms for $\mathrm{p} 53$ inhibition. We found a statistically significant lower proportion of lymphocytes were positive for $\mathrm{p} 53$ than were positive for PCNA and MDM2. This was also observed by Smolewski et al. in $1998,{ }^{31}$ who described mean reactivity of lymphocytes for PCNA of $39.6 \%$. According to most published studies, PCNA was expressed at higher frequencies than was p53.21,26,31 Histomorphometry was comparable to computed readings in the study by Sánchez-Beato et al. ${ }^{26}$ in 1996, for both markers.
Graph 4. Comparison of positive lymphocyte (L) expression for MDM2, p53 and proliferating cell nuclear antigen (PCNA).

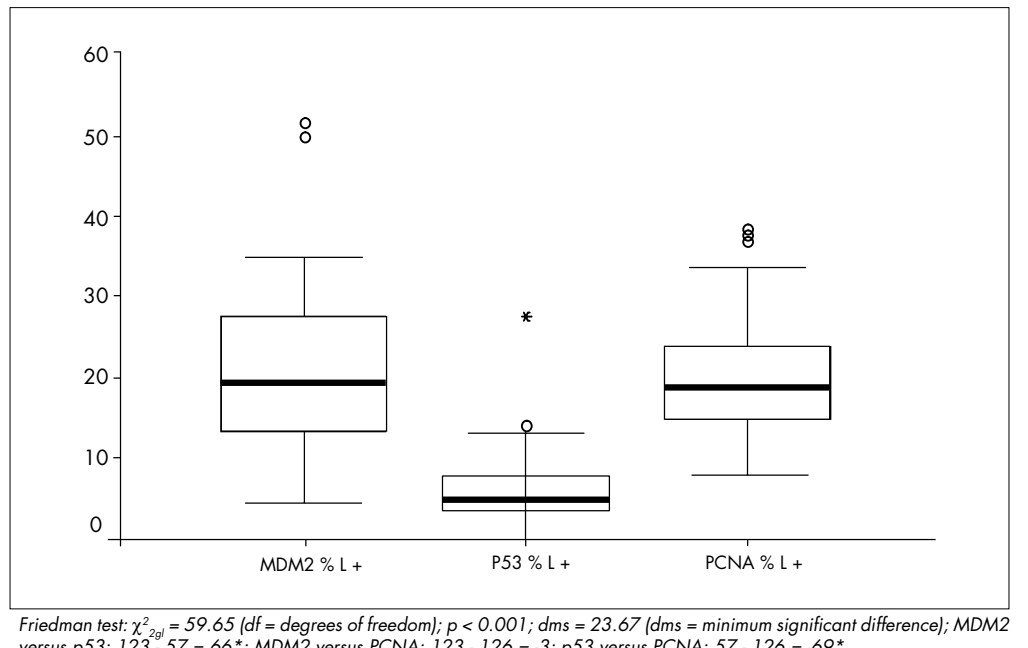
versus p53: $123^{29}-57=66^{*} ;$ MDM2 versus PCNA: $123-126=-3 ; p 53$ versus PCNA: $57-126=-69^{*}$

Table 2. Univariate analysis. Odds ratios (OR) for the percentage of positivity in Hodgkin and Reed-Sternberg cells (\%HRS+) ( $\geq$ mean or $<$ mean) for PCNA

\begin{tabular}{lllcc}
\hline Variable & N & OR & $95 \%$ Cl & P \\
\hline \%HRS+ for MDM2 & 51 & 0.35 & $0.113-1.095$ & 0.071 \\
\%HRS+ for p53 & 51 & 2.40 & $0.780-7.389$ & 0.127 \\
Alkaline phosphatase & 46 & 2.31 & $0.632-8.469$ & 0.205 \\
WBC & 51 & 1.56 & $0.496-4.898$ & 0.448 \\
ESR & 42 & 0.51 & $0.076-3.409$ & 0.486 \\
Histological subtype & 51 & 1.58 & $0.386-6.423$ & 0.526 \\
Age & 51 & 0.73 & $0.171-3.093$ & 0.666 \\
Clinical stage & 51 & 1.27 & $0.394-4.063$ & 0.692 \\
Hemoglobin level & 51 & 1.10 & $0.360-3.358$ & 0.867 \\
Gender & 51 & 0.94 & $0.304-2.886$ & 0.910 \\
B symptoms & 51 & 1.05 & $0.232-4.739$ & 0.952 \\
Bone marrow involvement & 48 & 1.00 & $0.219-4.564$ & $>0.999$ \\
\hline
\end{tabular}

$O R=$ odds ratio; $C l=$ confidence interval; $H R S=$ Hodgkin and Reed-Sternberg cells; $P C N A=$ proliferating cell nuclear antigen $W B C=$ whole blood count; $E S R=$ erythrocyte sedimentation rate

Table 3. Univariate analysis. Odds ratios (OR) for the percentage of positivity in Hodgkin and Reed-Sternberg cells (\%HRS+) ( $\geq$ mean or $<$ mean) for MDM2

\begin{tabular}{llccc}
\hline Variable & $\mathbf{n}$ & OR & $95 \% \mathbf{C l}$ & $\mathbf{p}$ \\
\hline \%HRS+ for PCNA & 51 & 0.35 & $0.113-1.095$ & 0.071 \\
Alkaline phosphatase & 46 & 0.31 & $0.080-1.204$ & 0.091 \\
Clinical stage & 51 & 1.81 & $0.556-5.886$ & 0.324 \\
B symptoms & 51 & 0.57 & $0.121-2.702$ & 0.481 \\
Histological subtype & 51 & 1.58 & $0.386-6.423$ & 0.526 \\
Age & 51 & 0.73 & $0.171-3.093$ & 0.666 \\
Hemoglobin level & 51 & 0.80 & $0.260-2.431$ & 0.688 \\
WBC & 51 & 0.79 & $0.255-2.476$ & 0.691 \\
ESR & 42 & 0.78 & $0.117-5.257$ & 0.802 \\
\%HRS+ for p53 & 51 & 0.92 & $0.308-2.769$ & 0.886 \\
Bone marrow involvement & 48 & 0.90 & $0.198-4.131$ & 0.897 \\
Gender & 51 & 0.94 & $0.304-2.886$ & 0.910 \\
\hline OR = odds ratio; HRS = Hodgkin and Reed-Sternberg cells; $P C N A=$ proliferating cell nuclear antigen; $\mathrm{Cl}=$ confidence interval;
\end{tabular}

$W B C=$ whole blood count; $E S R=$ erythrocyte sedimentation rate.
b 
Table 4. Univariate analysis. Odds ratios (OR) for the percentage of positivity in Hodgkin and Reed-Sternberg cells (\%HRS+) ( $\geq$ mean or $<$ mean) for p53

\begin{tabular}{lcccc}
\hline Variable & $\mathbf{n}$ & OR & 95\% IC & $\mathbf{p}$ \\
\hline \%HRS+ for PCNA & 51 & 2.40 & $0.780-7.389$ & 0.127 \\
Histological subtypes & 51 & 0.34 & $0.076-1.483$ & 0.150 \\
Age & 51 & 0.41 & $0.091-1.876$ & 0.252 \\
Clinical stage & 51 & 0.62 & $0.192-2.020$ & 0.324 \\
B symptoms & 51 & 1.92 & $0.406-9.046$ & 0.411 \\
Bone marrow involvement & 48 & 0.54 & $0.114-2.584$ & 0.443 \\
WBC & 51 & 1.56 & $0.496-4.898$ & 0.448 \\
Hemoglobin level & 51 & 1.52 & $0.496-4.685$ & 0.462 \\
ESR & 42 & 1.42 & $0.212-9.518$ & 0.717 \\
Alkaline phosphatase & 46 & 1.13 & $0.322-3.983$ & 0.845 \\
\%HRS+ for MDM2 & 51 & 0.92 & $0.308-2.769$ & 0.886 \\
Gender & 51 & 0.94 & $0.304-2.886$ & 0.910 \\
\hline OR = odds ratio; HRS = Hodgkin and Reed-Sternberg cells; $C l=$ confidence interval; PCNA = proliferating cell nuclear antigen;
\end{tabular}

$W B C=$ whole blood count; $E S R=$ erythrocyte sedimentation rate; $M D M 2=$ murine double minute- 2 antigen

Graph 5. Comparison of positive Hodgkin and Reed-Sternberg (HRS) cell expression for MDM2, p53 and proliferating cell nuclear antigen (PCNA).

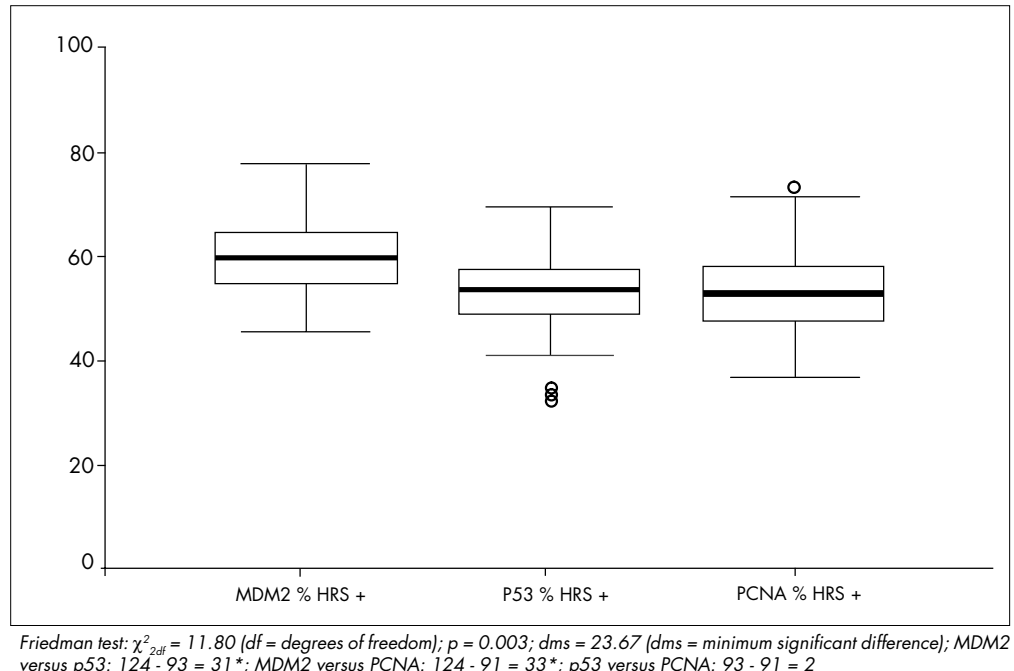

Friedman test: $\chi_{2 \text { df }}^{2}=11.80(\mathrm{df}=$ degrees of freedom); $p=0.003 ; \mathrm{dms}=23.67 \mathrm{dms}=$ minimum significan
versus $p 53: 124^{-}-93=31^{*} ;$ MDM2 versus PCNA: $124-91=33^{*} ; p 53$ versus $P C N A: 93-91=2$

Our data show that, in the "benign" inflammatory component of $\mathrm{HD}$, there are proliferating and differentiating lymphocytes that are morphologically normal but carry positivity for proliferation markers near to HRS cells. These lymphocytes may correspond to precursors of HRS, as proposed by Hell et al. ${ }^{27}$ in 1993 . The finding of higher expression of MDM2 than of PCNA and p53 in HRS cells may raise the possibility of a feedback mechanism between the $M D M 2$ and $p 53$ genes. ${ }^{31-33}$
The occurrence of spontaneous apoptosis, as evaluated by the TUNEL (in situ nick-end labeling) technique, ranged from 10 to $60 \%$ in HRS cells. The apoptosis index did not correlate with the histological and clinical findings, although a negative association with outcome was reported in 110 cases by Smolewski et al. ${ }^{32}$ Its presence is not influenced by the EBV genome in HRS cells. PCNA, p53, p21 and caspase 3 are associated with greater apoptosis indices, while BCL-2, MDM2, Rb-1 and P27 are not. ${ }^{32-35}$ In a smaller group of patients, it was confirmed that strong expression of PCNA, p53 and BCL-2 is associated with shorter OS and worse response to treatment. ${ }^{31,33}$ Brink et al. ${ }^{35}$ showed that the BCL-2+/p53- immunophenotype presented the worst prognosis, while the BCL-2-/p53- immunophenotype had five-year OS of more than $90 \%$ and the p53+/BCL-2+ immunophenotype had the best prognosis. ${ }^{35}$ High expressions of LMP1EBV in HRS cells presented better response to therapy and better OS, while Rb-1 had worse prognosis. p53, BCL-2 and CD15 did not influence the outcome. ${ }^{30,36-38}$ We emphasize that MDM2 and PCNA, MDM2 and p53 expression, and also $\mathrm{p} 53$ expression versus unfavorable histology were close to reaching significance in the univariate analyses. These data show that, if a larger sample were used, a significant result might be found, as observed by other authors. ${ }^{17-19,33-35,39}$

$\mathrm{B}$ symptoms and WBC counts higher than $10 \times 10 \% / \mu$ were unfavorable independent factors for achieving the first CR. Bone marrow tumor infiltration, B symptoms and hemoglobin levels less than $12 \mathrm{~g} / \mathrm{dl}$ had a negative influence on OS. These data have also been reported as negative prognostic factors for survival in HD. $24,32,34,39$ The present study was a retrospective analysis, but these findings have led us to attempt to be more specific regarding prognostic factors in this disease. ${ }^{38}$ The treatment for HD changed over the admission period for these patients, but the ratios of first $\mathrm{CR}$ and OS remained almost the same, because of the high sensitivity of the tumor to chemotherapy. ${ }^{34}$

CONCLUSIONS

The methods we have used showed that p53, PCNA and MDM2 are expressed in HRS cells at different intensities. Further studies with larger series are needed to elucidate the influence of Epstein-Barr virus infection, frequency of Rb-1 gene loss and high expression of P21 on the clinical setting and the relationship of these three factors to treatment response in HD patients. The finding of no clear association between the antigen expression evaluated and the clinical data may be explained by the limited number of patients, the retrospective nature of the study and the high expression of these proteins, which made stratification and the result interpretation methods used more difficult. 
1. Falini B, Stein H, Pileri S, et al. Expression of lymphoid-associated antigens on Hodgkin's and Reed-Sternberg cells of Hodgkin's disease. An immunocytochemical study on lymph node cytospins using An immunocytochemical study on lymph node cytospins using
monoclonal antibodies. Histopathology. 1987;11(12):1229-42.

2. Hsu SM, Hsu PL. Aberrant expression of T cell and B-cell markers in myelocyte/monocyte/histiocyte-derived lymphoma and leukemia cells. Is the infrequent expression of $T / B$ cell markers sufficient to establish a lymphoid origin from Hodgkin's Reed-Sternberg cells? Am J Pathol. 1989;134(1):203-12.

3. Morgan KG, Quirke P, O'Brien CJ, Bird CC. Hodgkin's disease: a flow cytometric study. J Clin Pathol. 1988;41(4):365-9.

4. Cossman J. Gene expression analysis of single neoplastic cell and the pathogenesis of Hodgkin's lymphoma. J Histochem Cytochem. 2001;49(6):799-800.

5. Spieker T, Kurth J, Kuppers R, Rajewsky K, Bräuninger A, Hansmann ML. Molecular single-cell analysis of the clonal relationship of small Epstein-Barr virus-infected cells and Epstein-Barr virus-harboring Hodgkin and Reed/Sternberg cells in Hodgkin disease. Blood. 2000;96(9):3133-8.

6. Kuppers R, Sousa AB, Baur AS, Strickler JG, Rajewsky K, Hansmann ML. Common germinal-center B-cell origin of malignant cells in two composite lymphomas, involving classical Hodgkin's disease and either follicular lymphoma or B-CLL. Mol Med. 2001; 7(5):285-92.

7. Stein $\mathrm{H}, \mathrm{Hummel} \mathrm{M}$. Cellular origin and clonality of classic Hodgkin's lymphoma: immunophenotypic and molecular studies. Semin Hematol. 1999;36(3):233-41.

8. Falini B, Fizzotti M, Pucciarini A, et al. A monoclonal antibody (MUM1p) detects expression of the MUM1p/IRF4 protein in a subset of germinal center B cells, plasma cells, and activated T cells. Blood. 2000;95(6):2084-92.

9. Foss HD, Reusch R, Demel G, et al. Frequent expression of the B-cell-specific activator protein in Reed-Sternberg cells of classical Hodgkin's disease provides further evidence for its B-cell origin. Blood. 1999;94(9):3108-13.

10. Sabattini E, Gerdes J, Gherlinzoni F, et al. Comparison between the monoclonal antibodies Ki-67 and PC10 in 125 malignant lymphomas. J Pathol. 1993;169(4):397-403.

11. Garcia RL, Coltrera MD, Gown AM. Analysis of proliferative grade using anti-PCNA/cyclin monoclonal antibodies in fixed, embedded tissues. Comparison with flow cytometric analysis. Am J Pathol. 1989;134(4):733-9.

12. Naresh KN, O'Conor GT, Soman CS, et al. A study of p 53 protein, proliferating cell nuclear antigen, and p 21 in Hodgkin's disease at presentation and relapse. Hum Pathol. 1997;28(5):549-55.

13. Levine AJ, Momand J, Finlay CA. The p 53 tumour suppressor gene. Nature. 1991;351(6326):453-6.
14. Fritsche M, Haessler C, Brandner G. Induction of nuclear accumulation of the tumor-suppression protein $\mathrm{p} 53$ by DNAdamaging agents. Oncogene. 1993;8(2):307-18.

15. Trümper LH, Brady G, Bagg A, et al. Single-cell analysis of Hodgkin and Reed-Sternberg cells: molecular heterogeneity of gene expression and p53 mutations. Blood. 1993;81(11):3097-115.

16. Xerri L, Bouabdallah R, Camerlo J, Hassoun J. Expression of the p53 gene in Hodgkin's disease: dissociation between immunohistochemistry and clinicopathological data. Hum Pathol. 1994;25(5):449-54

17. Chilosi M, Doglioni C, Menestrina F, et al. Abnormal expression of the p53-binding protein MDM2 in Hodgkin's disease. Blood. 1994;84(12):4295-300.

18. Elenitoba-Johnson KS, Medeiros LJ, Khorsand J, King TC. P53 expression in Reed-Sternberg cells does not correlat with gene mutations in Hodgkin's disease. Am J Clin Pathol. 1996;106(6):728-38

19. Xerri L, Parc P, Bouabdallah R, Camerlo, J, Hassoun J. PCRmismatch analysis of $\mathrm{p} 53$ gene mutation in Hodgkin's disease. J Pathol. 1995;175(2):189-94

20. Chen WG, Chen YY, Kamel OW, Koo CH, Weiss LM. p53 mutations in Hodgkin's disease. Lab Invest. 1996;75(4):519-27.

21. Martinez JC, Mateo M, Sanchez-Beato M, et al. MDM2 expression in lymphoid cells and reactive and neoplastic lymphoid tissue. Comparative study with p 53 expression. J Pathol. 1995; 177(1):27-34.

22. Weiss L, Chen YY, Liu XF, Shibata D. Epstein-Barr virus and Hodgkin's disease. A correlative in situ hybridization and polymerase chain reaction study. Am J Pathol. 1991;139(6):1259-65

23. Tzardi M, Kouvidou C, Panayiotides I, et al. Expression of $\mathrm{p} 53$ and $\mathrm{mdm}-2$ proteins in Hodgkin's Disease. Absence of correlation with the presence of Epstein-Barr virus. Anticancer Res. 1996; 16(5A):2813-9.

24. Yuen AR, Horning SJ. Recent advances in Hodgkin's disease. Curr Opin Hematol. 1996;3(4):273-8.

25. Hsu SM, Raine L, Fanger K. Use of avidin-biotin-peroxidase complex $(A B C)$ in immunoperoxidase techniques: a comparison between $\mathrm{ABC}$ and unlabeled antibody (PAP) procedures. Histochem Cytochem. 1981;29(4):577-80.

26. Sánchez-Beato M, Piris MA, Martínez-Montero JC, et al. MDM2 and p21WAF1/CIP1, wild-type p53-induced proteins. are regularly expressed by Sternberg-Reed cells in Hodgkin's disease. J Pathol. 1996;180(1):58-64.

27. Hell K, Lorenzen J, Hansmann ML, Fellbaum C, Busch R, Fischer R. Expression of the proliferating cell nuclear antigen in the different types of Hodgkin's disease. Am J Clin Pathol. 1993;99(5):508-603
28. Schmid C, Sweeney E, Isaacson PG. Proliferating cell nuclear antigen (PCNA) expression in Hodgkin's disease. J Pathol. 1992;168(1):1-6.

29. Martinez-Delgado B, Robledo M, Arranz E, et al. Correlation between mutations in $\mathrm{p} 53$ gene and protein expression in human lymphomas. Am J Hematol. 1997;55(1):1-8.

30. Niedobitek G, Rowlands DC, Young LS, et al. Overexpression of p53 in Hodgkin's disease: lack of correlation with Epstein-Barr virus infection. J Pathol. 1993;169(2):207-12.

31. Smolewski P, Niewiadomska H, Blonski JZ, Robak T, Krykowski E Expression of proliferating cell nuclear antigen (PCNA) and $\mathrm{p} 53$ bcl-2 or C-erb B-2 proteins on Reed-Sternberg cells: prognostic significance in Hodgkin's disease. Neoplasma. 1998;45(3):140-7.

32. Smolewski P, Niewiadomska H, Los E, Robak T. Spontaneous apoptosis of Reed-Sternberg and Hodgkin cells; clinical an pathological implications in patients with Hodgkin's disease. Int J Oncol. 2000;17(3):603-9.

33. Smolewski P, Niewiadomska H, Krykowski E, Robak T. Expression of p21 and MDM-2 proteins on tumor cells in responding and non-responding patients with Hodgkin's disease. Neoplasma. 1999;46(4):212-8.

34. Smoleswski P, Robak T, Krykowski E, et al. Prognostic factors in Hodgkin's disease: multivariate analysis of 327 patients from a single institution. Clin Cancer Res. 2000;6(3):1150-60.

35. Brink AA, Oudejans JJ, van den Brule AJ, et al. Low p 53 an high bcl-2 expression in Reed-Sternberg cells predicts poo clinical outcome for Hodgkin's disease: involvement of apoptosis resistance? Mod Pathol. 1998;11(4):376-83.

36. Montalban C, Abraira V, Morente M, et al. Epstein-Barr viruslatent membrane protein 1 expression has a favorable influence in the outcome of patients with Hodgkin's Disease treated with chemotherapy. Leuk Lymphoma. 2000;39(5-6):563-72.

37. Murray PG, Billingham LJ, Hassan HT, et al. Effect of EpsteinBarr virus infection on response to chemotherapy and survival in Hodgkin's disease. Blood. 1999;94(2):442-7.

38. Spector N, Milito CB, Biasoli I, Luiz RR, Pulcheri W, Morai JC. The prognostic value of the expression of Bcl-2, p53 and LMP-1 in patients with Hodgkin's lymphoma. Leuk Lymphoma. 2005;46(9):1301-6.

39. Montalban C, Garcia JF, Abraira V, et al. Influence of biologic markers on the outcome of Hodgkin's lymphoma: a study by the Spanish Hodgkin's Lymphoma Study Group. J Clin Oncol. 2004;22(9):1664-73.

Sources of funding: None

Conflict of interest: None

Date of first submission: June 15, 2004

Last received: April 8,2007 
AUTHQR INFRRMATION

Gevina Silva Pinheiro, MD. Postgraduate student, Division of Hematology and Transfusion Medicine, Hospital São Paulo, Universidade Federal de São Paulo - Escola Paulista de Medicina, São Paulo, Brazil.

Maria Regina Régis Silva, MD, PhD. Associate professor, Department of Pathology, Universidade Federal de São Paulo - Escola Paulista de Medicina, São Paulo, Brazil.

Celso Arrais Rodrigues, MD, PhD. Postgraduate student, Division of Hematology and Transfusion Medicine, Hospita São Paulo, Universidade Federal de São Paulo - Escola Paulista de Medicina, São Paulo, Brazil.

José Kerbauy, MD, PhD. Titular professor, Department of Medicine. Division of Hematology Universidade Fedra de SE Paulo -

José Salvador Rodrigues de Oliveira MD, PhD. Associate professor, Department of Medicine, Division of Hematology, Universidade Federal de São Paulo - Escola Paulista de Medicina, São Paulo, Brazil.

\section{Address for correspondence}

José Salvador Rodrigues Oliveira

Departamento de Medicina, Divisão de Hematologia Universidade Federal de São Paulo - Escola Paulista de Medicina

Rua Botucatu, $740-3^{\circ}$ andar

São Paulo (SP) - Brasil - CEP 04023-900

Tel. (+55 11) 5576-4237 / 1+55 11) 5576-4240

Fax $(+5511) 5571-8806$

E-mail: salvador@hemato.epm.br

Copyright $\odot$ 2007, Associação Paulista de Medicina
RESUMD

Proliferação de antígeno de célula nuclear (PCNA), p53 e expressão de MDM2 em doença do Hodgkin

CONTEXTO E OBJETIVO: As células tumorais da doença de Hodgkin (HD) são positivas para marcadores de proliferação celular que são analisados por seus genes e respectivas proteínas. A correlação entre a expressão destas proteínas e os parâmetros clínico-laboratoriais são, no momento, de importância para o prognóstico da doença.

TIPO DE ESTUDO E LOCAL: Estudo retrospectivo da expressão do antígeno de proliferação celular (PCNA) e da p53 e MDM2 em tecidos obtidos ao diagnóstico, fixados por formol, embebidos em parafina de 51 pacientes com HD. O trabalho foi realizado na Divisão de Hematologia e Transfusão, Hospital São Paulo, Universidade Federal de São Paulo.

MÉTODOS: As expressões antigênicas foram analisadas através da proporção de células de Hodgkin e células de Reed Sternberg (HRS) e linfócitos reacionais (L) positivos. A intensidade de expressão de cada proteína foi comparada entre L e HRS através do coeficiente de Spearman. A comparação da PCNA, p53 e MDM2 em L e HRS se fez pelo teste de Fiedman. As correlações entre variáveis clínico-laboratoriais, comprometimento da medula óssea, taxas de sobrevida geral e remissão clínica com as proteínas em HRS se fizeram pelo coeficiente de Pearson.

RESULTADOS: Houve superexpressão das três proteínas em células HRS comparadas aos $L(p<0,001)$. Nas células HRS, a MDM2 foi maior que a p53 e a PCNA $(p<0,003)$, que foram equivalentes. Nos $L$, a p53 foi menor que a MDM2 e a PCNA ( $p<0,001)$, que foram equivalentes Não houve relação entre as expressões das proteínas com as variáveis clínico-laboratoriais e sobrevida.

CONCLUSÕES: PCNA, p53 e MDM2 são marcadores tumorais na HD, porém não mostraram significado clínico-prognóstico em nossa análise.

PALAVRAS-CHAVE: Antígeno nuclear de célula em proliferação. Genes p53. Proteínas proto-oncogênicas c-mdm2. Doença de Hodgkin. Imunohistoquímica. 